\title{
PENERAPAN MODEL EXPERIENTIAL LEARNING PADA SEKOLAH ALAM UNTUK MENCIPTAKAN PEMBELAJARAN YANG MENYENANGKAN
}

\section{APPLICATION OF EXPERIENTIAL LEARNING MODEL IN SCHOOL OF NATURE TO CREATE EXCITING LEARNING}

\author{
SW Pujaningtyas ${ }^{1 a}$, B Kartakusumah ${ }^{1}$, dan A Mulyana1 \\ 1 Program Studi Manajemen Pendidikan Islam, Fakultas Keguruan dan Ilmu Pendidikan, \\ Universitas Djuanda Bogor, Jl. Tol Ciawi No. 1 Kotak Pos 35 Ciawi Bogor 16720 \\ a Korespondensi: Sri Wahyu Pujaningtyas, Email: aningningtyas@gmail.com
}

(Diterima: 28-12-2018; Ditelaah: 02-01-2019; Disetujui: 20-03-2019)

\begin{abstract}
The role of teachers in the learning process that can generate activity learners that is by running one of the main tasks of learning management. A very important learning management activity is carried out, including planning, implementation and evaluation of learning. The application of experiential learing model at nature school optimizes nature and local potential as a learning resource. Experiential learning is a model of learning that became one of the models applied to natural schools. This study aims to determine the management of experiential learning model in natural school, which includes planning, implementation, and evaluation of learning in implementari school Alam Cikeas. This research uses qualitative approach, with Case Study method. Qualitative approach with case study method is used to study and answer the problem and to get deeper meaning about experiential learning model management. Preparation of learning planning by applying experiential learning model at SD Alam Cikeas becomes the duty and responsibility of every classroom teacher, made with reference to curriculum of National Education and natural school curriculum. Experiential model is implemented by optimizing the nature and local potential that is available in SD Alam Cikeas as a means and learning resource. Learning activities include gardening, outbound, recycling waste. Evaluation is done after the activity ends by giving the worksheet, through the work, the interview, besides through the assessment of the activity of the students.
\end{abstract}

Keywords: experiential learning model, management of learning.

\section{ABSTRAK}

Peran pendidik dalam proses belajar mengajar yang dapat membangkitkan motivasi belajar peserta didik yakni dengan menjalankan salah satu tugas yang utama yakni pengelolaan pembelajaran. Kegiatan pengelolaan dan pengaturan pembelajaran yang sangat perlu dijalankan, diantaranya ialah perencanaan, pelaksanaan dan evaluasi hasil pembelajaran. Penerapan peembelajaran model experiental di Sekolah Alam mengoptimalkan alam dan potensi lokal sebagai sumber belajar. Model pembelajaran Experiential merupakan model pembelajaran yang menjdi salah satu model yang diterapkan pada sekolah alam. Penelitian ini bertujuan untuk mengetahui pengelolaan pembelajaran model experiential pada sekolah alam, yang meliputi perencanaan, pelaksanaan, dan evaluasi hasil pembelajaran di SD Alam Cikeas. Penelitian ini menggunakan pendekatan kualitatif, dngan metode Studi Kasus. Pendekatan kualitatif dengan menggunakan metode studi kasus ini digunakan untuk mengkaji dan menjawab permasalahan serta untuk memperoleh makna yang mendalam mengenai pengelolaan pembelajaran model experiential. Penyusunan perencanaan 
pembelajaran yang menerapkan model pembelajaran experiental di SD Alam Cikeas menjadi tugas dan tanggungjawab setiap guru kelas, dibuat dengan berpedoman pada kuriikulum Pendidikan Nasional dan kurikulum sekolah alam. Model experiential dilaksanakan dengan mengoptimalkan alam dan potensi lokal yang tersedia di lingkungan SD Alam Cikeas sebagai sarana dan sumber dalam kegiatan belajar. Kegiatan pembelajaran tersebut diantaranya berkebun, outbond, mengolah sampah. Evaluasi hasil belajar dilaksanakan setelah kegiatan berakhir dengan memberikan worksheet, melalui hasil karya, wawancara, selain itu melalui penilaian aktivitas gerak peserta didik.

Kata kunci: model experientil learning, pengelolaan pembelajaran.

Pujaningtyas, S. W., Kartakusumah, B., \& Mulyana, A. (2019). Pengelolaan Model Experiential Learning pada Sekolah Alam untuk Menciptakan Pembelajaran yang Menyenangkan. Tadbir Muwahhid, 3(1), 40-52.

\section{PENDAHULUAN}

Proses pendidikan kini beralih dari yang berfokus pada pendidik menjadi berfokus pada keaktifan peserta didik. Perubahan kurikulum yang diiterapkan dalam dunia pendidikan saat ini menekankan pada keterlibatan secara aktif siswa dalam proses pembelajaran. Hal ini ditegaskan dengan kebijakan pelaksanaan kurikulum 2013 oleh kemendikbud (2013) dimana pembelajaran yang dikembangkan pendidik yakni pembelajaran aktif yang berfokus pada keaktifan siswa dan guru sebagai fasilitator. Sebagai suatu bentuk rencana program belajar, kurikulum tidak bermakna apabila tidak diimplementsikan dalam bentuuk pembelajaran. Untuk itu implementasi pembelajaran sangatlah penting sebagai perwujudan rencana program.

Pembelajaran yang merupakan proses yang komplek dan melibatkan berbagai aspek yang saling berkaitan satu sama lain. Berbagai aspek yang saling berkaitan tersebut diantaranya adalah komponen guru. Menjadi guru profesional, yang memiliki kreatifitas dengan metode menyenangkn dittuntut untuk mempunyai kemampuan dalam mengembangkan pendkatan dan memilih metod dan model pembelajarann yang sesuai. Mengingat pentingnya peran pendidik dalam hal ini, untuk itu sangat diperlukan kemampuan dalam mengelola kegiatan pembelajaran. Upaya untuk dapat meniingkatkan keberhasila belajar siswa dapat dilakukan diantaranya melalui memperbaiki proses pembelajaran. Dalam memperbaiki proses pembelajaran ini peranan pendidik sangat peting, yaitu menetapkan model pembelajaran yang tepat sesuai dengan konsep ilmu yang akan disampaikan.

Penerapan manajemen pada pembelajaran yang menjadi salah satuu probelm yang dihadapi dalam dunia pendidikan merupakan tanggungjawab guru secara operasional. Peran pendidik dalam prosess pembelajaran yang mampu membangkitkan aktivitas belajar siswa yakni dengan menjalankan salah satuu tugas utama yakni dalam pengelolaan pembelajaran. Aktivitas pengelolaan pembelajaran diantaranya; melakukan perencanaan yang merupakan bentuk antisipasi dan memperkirakan apa yang akaan dilakukan dalam proses pembelajaran. Setelah itu pendidik bertangguung jawab secara langsung untuk melaksnakan kegiiatan pembelajaaran yang telah direncanakan. Atas dasar pembelajaran berorientasi pada tujuan, maka pelaksanaan evaluasi dipandang 
penting untuk mengukuru ketercapaian siswa dalam belajar.

Pemilihan model pembelajaran yang tepat, perlu dilakukan agar tujuan pembelajaran dapat tercapai yang akan berdampak pada peningkatan hasil belajar siswa. Salah satu model pembelajaran yang cukup efektif untuk diterapkan yakni experiential learning. Experiential Learning menekankan kepada keaktifan dan keterlibatan siswa dalam proses pembelajaran yakni dengan memberikan pengalaman belajar secara langsung. Ahli yang mengembangkan model ini, Jonh Dewey berpendapat bahwa sebuah pengalaman bisa menyebabkan pembelajaran bahkan bisa menyebabkan perubahan (Silberman, 2007). Untuk itu model pembajaran ini menekankan siswa agar memperoleh pemahaman terhadap suatu konsep berdasarkan pengalaman belajar yang alami siswa.

Sekolah alam yang merpakan lembaga pendidikan alternatif, menjadi sekolah yang melekat dengan model pembelajaran experiential, dimana proses pemblajaran di sekolah alam lebih memanfaatkan lingkungan alam sebagai sumber belajar. Sekolah alam merupakan fasilitas pendidikan dengan konsep pengembagan pendidikan secara alami. Lingkungan sekolah alam terasa natural dengan bangunan sekolah berupa rumah panggung dan dikelingi oleh berbagai kebun, tanaman buah, sayur, bunga bahkan area peternakan. Proses pendidikan dalam sekolah alam sangat memperhatikan potensi setiap individu, kebebasan untuk mengaktualisasi diri sesuai kreativitasnya. Hal ini menumbuhkaan kemauan dalam diri siswa dalamm belajar, sehingga memungkinkan terciptanya liingkungan belajar yang menyenangkan. Secara naluriah, beljar di alaam terbuka akan menumbuhkan suasana tanpa rasa tekanan dan kebosanan. Hal ini akan membantu siswa dalam mendapatkan pengalaman konkret sekaligus membangun imajinasi positif tentang manusia dan lingkungannya. penggabungan antara pelajaran dikelas, pelatihan (outbond), observasi lapangan (outing), wirausaha dan lain lain telah memberikan kesdaran dan pemhaman yang relatiff lebih utuh tntang kehidupan, yang dapat membentuk emosis dan mentalitas yang stabiil, serta membangun perlaku sehari-hari yang lebih tercerahkan

Peserta didik diarahkan agar belajar secara aktif dan mandiri, peserta didik lebih berperan sbagai fasilitator. Orientasi belajar mereka tidak semata utuk mengejar nilai, tetapi untuk memanfaatkan ilmu pengetahuan yang diperolehnya dalam kehidupan sehari-hari. penggabungan antara pelajara di kels, latihan (outbond), penelitian lapngan (outing), wirausaha dan lain lain telh memberikn kesadaran dan pemahamaan yang lebih utuh tentang kehiidupan, yang dapat membentuk emsi dan mentalitas yng stabil, serta membanguun siikap-sikap keseharian yang lebih tercerahkan.

Salah satu sekolah alam terbaik di Bogor yakni, SD Alam Cikeas yang telah bersertifikasi ISO 9001 pada kualitas manajemen. Pembelajara di SD Alam Cikeas banyak dilakukan di ruangg terbuka, dengan memanfaaatkan sumber belajar yang ada dilingkungan sekolah alam. SD Alam Cikeas merupakan sebuah sekolah berbasis alam yang memiliki misi untuk membentuk generasi berkrakter mulia melalui pendidikan kreatif yang berwaawasan lingkungan. SD Alam Cikeas mengaplikasikan model pembelajran yang meneknkan pada pengalaman belajar (Experiential Learning) dengan mengoptimalkan alam dan potensi lokal 
sebagai sumber belajar. Lingkungan SD Alam Cikeas sendiri diciptakan sealamiah mungkin agar tercipta proses pembelajaran berbasis alam, didukung dengan berbagai fasilitas dan sarana, sehingga menciiptakan suasana belaajar yang menyenangkan dan jauh dari kejenuhan.

\section{METODE}

\section{Jenis Penelitian}

Pendekatan penelitian yang digunakan yaiu pendekatan kualitatiif dengan jenis penelitian yaitu penelitian Studii Kasus (Case Study). Penelitian studi kasus adalh suatu proses mengumpulkan data dan informsi secara mendaalam, mendetaiil, intensif, holistik, dan sistematis dengan menggunakan berbagaii metodde dan teknik serta banyak suumber informsi untuk memahaami secara efektiff orang, kejadian, laatar alami itu beroperasi dan brfungsi sesuai dengan konteksnya (Yusuf, 2014).

Sumber datta diperoleh dari subyek yang terkait dalam penelitian yaitu pimpinan sekolah, guru, dan fasilitator model experiential learning. Untuk menemukan data yang benar tentang pengelolaan pembelajaran model experiential pada sekolah alam untuk menciptakan pembelajaran yang menyenangkan, peneliti menggunakan teknik pengumpuln data melalui observasi, wawancara, dan studi dokumentasi. Selanjutnya untuk menganalsis data yang telah terkumpul sejak awal sampai akhir peneliti menggunakan reduksi data, penyajian data dan kesimpulan.

\section{Waktu dan Tempat Penelitian}

Waktu penelitian dimulai pada bulan Februari hingga Mei 2018, mulaii dari observasi sampai pada penulisn laporan penelitiann. Penelitian dilakukkan di SD Alam Cikeas yng terletak di Kompleks Puri Cikeas, Jl. Letda Natsir, Gunung Putri Bogor.

\section{Target/ Subjek Penelitian}

Target/Subjek Penenlitian ini adalah pengelolaan model pembelajaran experintial pada sekolah alam. Meliputi perencanaan, pelaksanaan, dan evaluasi model pembelajaran experiential pada sekolah alam untuk mencipatakan pembelajaran yang menyenangkan.

\section{Prosedur Penelitian}

Prosedur penelitian dilakukan melalui tahap analisis sebelum lapangan, dan analisis selama di lapangan. Analisis selama dilapanan menggunakan midel Miles dan Huberman, dengan langkah-langkah: melakukan reduksi data, menyajikan data kedalam pola, dan melakukan verivikasi terhadap data yang diperoleh.

\section{Data, Instrumen, dan Teknik Pengumpulan Data}

Data dalam penelitian ini yaitu data kualitatif yang disajikan dalam bentuk verbal. data diperoleh melalui sumber data primer melalui wawancara dengan pimpinan sekolah, wakil kepala sekolah, guru, fasilitator, dan siswa. Serta data sekunder diperoleh melalui arsip dan dokumen terkait objek yang diteliti. Data dikumpulkan melalui instrumen pertanyaan yang diajukan kepada informan. Teknik pengumpulan data dilakukan dengan wawancara, observasi dan studi dokumentasi.

\section{Teknik Analisis Data}

Teknik analisis data kualitatif ini bersifat induktif. Dari data yang didapat kemudian dikembangkan menjadi hipotesis. Hipotesis 
dirumuskan berdasarkan data tersebut, kemudian dicarikan data lagi secara berulang-ulang hingga dapat disimpulkan. Data yang dikumpulkan kemudian dilakukan pengecekan data dari (triangulasi) dengan berbagai cara dan waktu.

\section{HASIL DAN PEMBAHASAN}

\section{Hasil}

Hasil penelitian ini akan menginterpretasikan hasil temuan peneliti di lapangan yang telah diperoleh. Pembahasan dari hasil penelitian ini dimaksudkan untuk memberikan pejelasan terhadap hasil penelitian yang selaras dengan kajian teori yang digunakan. Pembahasan tersebut dikemukakan sebagai berikut:

\section{Perencanaan Model Pembelajaran Experiential}

Berdasarkan hasil wawancara, observasi, dan studi dokumentasi di SD Alam Cikeas Bogor terkait dengan perencanaan model pembelajaran experiential pada Sekolah Alam. Seluruh proses pendidikan yang ada di sekolah, pembelajaran ialah suatu aktivitas yang lebih utama dibandingkan dengan aktivitas yang lain. Pada dasarnya perubahan perilaku yang disadari dan cenderung bersifat tetap merupakan hasil proses pembelajaran dari suatu proses belajar yang dilakukan secara berulang. (Thobbroni, 2015). Pengelolaan pembelajaran itu sendiri bermakna sebagai proses dari penyelenggaraan interaksi siswa dengan guru dan sumber belajar dalam lingkungan belajar. Kegiatan pengelolaan pembelajaran meliputi; menyusun perencanaan, pelaksanaan pembelajaran, pengorganisasian serta evaluasi pembelajaran.

Perangkat perencanaan proses pembelajaran terdiri dari silabus dan Rencama Pelaksanaaan Pembelajaraan (RPP) yang didalamnnya terdapat identitas mata pelajaran, standar kmpetensi (SK), kompetensi dasar (KD), indkator pencapaian kompetensi, tujuan pembelajarn, model dan metode pembelajaran, penilalaian hasiil belajar, serta sumber belajar. Rencana Pelaksanaan Pembelajaran merupakan penjabaran dari silabus yang terdiri dari identitas mata pelajaran, tema, SK, KD, materi, kegiatan, indikator pencapaian kompetensi, penialain, penggunaan waktu, dan sumber belajar.

Kalender akademik merupakan salah satu perangkat perencanaan pembelajaran yang memiliki fungsi sebagai panduan bagi guru dalam merencanakan program pembelajaran. Memuat dan menjabarkan rencana kegiatan belajar maupun program kerja sekolah dalam jangka waktu satu tahun ajaran. Kalender akademik SD Alam Cikeas dibuat setiap tahun ajaran dan telah disusun sampai dengan tahun ajaran berikutnya. Hal ini dilakukan agar lebih mempermudah dalam mempersiapkan segala sesuatu terkait dengan kegiatan pembelajaran. Proses perencanaan pembelajaran di SD Alam Cikeas diawali dengan penyelenggaraan rapat kerja tahunan. Rapat kerja tahunan membahas berbagai hal terkait dengan rencana program yang akan dilaksanakn dalam satu tahun kedepan diantaranya, evaluasi program sebelumnya, pembagian tugas guru dan karyawan, penyusunan jadual pelajaran dan lain-lain. SD Alam Cikeas diaawal tahun biasa menentukan tema besar yang akan menjadi acuan dalam kegiatan pembelajaran dalam setahun. Pada 
tahun ajaran 2018/2019 ini tema yang diangkat ialah biodiversity (keragaman hayati), untuk itu setiap pembelajaran akan diintegrasikan pada tema tersebut. Disamping itu kegiatan pembelajaran juga mengacu pada tema yang sudah ditentukan Diknas. Kurikulum yang digunakan SD Alam Cikeas mengacu pada kurikulum pendidikan nasional dan kurikulum sekolah alam. Penyusunan lesson plan, dilakukan oleh pendidik setiap tahunnya. Lesson plan atau yang umum disebut dengan RPP menjabarkan rencana kegiatan belajar, model serta metode yang digunakan, media dan alat bantu belajar yang digunaakan, buku referensi yang digunakan, lembar penilaian baik penilaian pengetahuan dan keterampilan.

SD Alam Cikeas mengupayakan untuk dapat lebih banyak menggunakan model experiential dalam pembelajarannya. Hal ini selaras dengan konsep sekolah alam yakni belajar dengan eksplorasi, eksperimen, dan lain sebagainya. Untuk itu kegiatan pembelajaran yang direncanakan dilakukan dengan $75 \%$ kegiatan outdoor dan 25\% kegiatan indoor. SD Alam Cikeas merupakan sekolah dasar yang menerapkan fullday school, hal ini karena waktu yang dibutuhkan untuk implementasi pembelajaran berbasis sekolah alam. Dalam perencanaanya, penerapan model experiential ini, guru harus mempersiapkan bagaimana teknis pelaksanaan serta alat dan bahan apa yang dibutuhkan untuk menunjang pelaksanaan model pembelajaran experiential. Pembelajaran model experiential yang khas dilaksanakan di SD Alam Cikeas diantaranya greenlab (berkebun), beternak, mengelola sampah, dan outbond.

Persiapan pembelajaran dengan model experiential dilakukan dengan melakukan beberapa tahapan. Tahap pertama yang dilakukan yakni guru menyampaikan kepada siswa tentang apa yang akan dipelajari, diselidiki, atau diteliti. Kemudian menjelaskan apa saja yang harus dilakukan siswa selama pelaksanaan model pembelajaran eksperiential serta menyiapkan alat dan bahan yang akan digunakan. Evaluasi model experiential dilakukan pada akhir kegiatan pengamatan dan penelitian. Guru memberikan lembar kerja yang akan digunakan untuk bahan evaluasi pembelajaran experiential. Lembar kerja ini dapat berupa lembar pengamatan, baik kerja kelompok maupun individu. Lembar kerja tersebut akan dilaporkan pada akhir kegiatan.

Dalam menyusun perencanaan pembelajaran guru melakukan review terhadap buku panduan pendidikan nasional, dan menyimpulkannya. Kemudian dibuat spiderweb, semesterplan, weekly plan dan daily plan. Perencanaan dibuat juga dengan menyesuaikan kurikulum sekolah alam dan tema tahunan yang telah dtentukan.

Dalam penetuan Kriteria Ketuntasan Minimum (KKM), guru menetapkan KKM pada setiap mata pelajaran. Penetapan KKM, dihitung berdasarkan tingkat kompleksitas, intake siswa, kemampuan guru dan sarana prasana. Kompleksitas merupakan tingkat kerumitan mata pelajaran tersebut, dari aspek tersebut guru dapat menentukan standar nilai yang bisa dicapai peserta didik, selain itu dilihat pula kemampuan peserta didik dan kemampuan guru dalam menyampaikan materi yang akan diajarkan. Sarana dan prasarana yang menunjang pembelajaran, juga menjadi bagian dari aspek yang dilhat dalam penentuan nilai KKM. Setelah melihat aspek-aspek tersebut guru dapat menentukan standar KKM yang bisa dicapai peserta didik. 
Dalam penyusunan spiderweb, guru melakukan bedah buku dan bahan ajar untuk dijadikan panduan dalam menentukan uraian bahasan yang harus disampaikan. Dalam pelaksanaannya guru mengembangkan metode belajar sendiri. Dalam hal ini guru harus pandai dalam mengatur materi yang akan diajarkan. Pembelajaran saling diintegrasikan dengan tema yang sedang dipelajari. Pada tahap selanjutnya ialah penyusunan weeklyplan. Weeklyplan merupakan uraian rencana kegiatan yang direncanakan auntuk dilakukan dalam kurun waktu satu minggu. Weeklyplan berisi tujuan pembelajaran yang ingin dicapai juga apa yang ingin dimunculkan dari pembelajaran tersebut.

Dari weeklyplan tersebut kemudian disusun dailyplan. Daily plan atau yang umum dikenal RPP, digunakan guru sehari hari sebagai acuan dalam melaksanakan pembelajaran dikelas. Dalam dailyplan juga dipaparkan tools atau alat bantu seperti media pembelajaran yang akan digunakan untuk menunjang pelaksanaan pembelajaran serta memaparkan model dan metode pembelajaran yang akan digunakan.

\section{Pelaksanaan Experiential Learning}

Model pembelajaran experiential sudah sangat identik pada sekolah Alam. Model pembelajaran experiential bertujuan untuk mengembangkan pemahaman dan capaian hasil belajar lainnya melalui tranformasi pengalaman. Pengalaman sebagai proses dan sumber belajar merupakan fokus utama model pembelajaran ini. Didukung dengan lingkungan belajar yang diciptakan sekolah alam, sehingga memungkinkan pelaksanaan model pembelajaran experiential ini. Model ini menekankan dua pendekatan yang sling berkaitan dalam memahami sebuah pengalaman yakni pengalaman konkret dan konseptualisasi abstrak, serta dua pendekatan dalam mengubah pengalaman yakni observasi refleksi dan eksperimen aktif. Konsep sekolah SD Alam Cikeas yakni belajar melalui alam maka hal ini menbuat pembelajaran di Sekolah Alam lebih bamyak melakukan aktifitas outdoor dengan mengutamakan pada pengalaman belajar peserta didik secara langsung.

SD Alam Cikeas, mengupayakan untuk bisa memaksimalkan metode belajar yang menyenangkan bagi peserta didiknya melalui media alam. Pelaksanaan pembelajaran itu sendiri merupakan kegiatan yang bernilai edukatif, nilai edukatif dalam hal ini interaksi yang terjaid antara guru dan siswa karena pembelajaran dilakukan diarahkan untuk mencapai tujuan belajar yang telah dirunuskan dalam perencanaan pembelajaran. Dalam pelaksanaan pembelajaran, guru melaukan beberapa tahapan pelaksanaan pembelajaran antara lain : 1) membuka pelajaran dilakukan untuk menciptakan suasana yang dapat membuat siswa siap secara mental untuk mengikuti kegiatan. 2) penyampaian materi pembelajaran; merupakan inti dari suatu proses pelaksanaan pembelajaran. Pada proses ini guru menggunakan model dan metode mengajar yang sesuai dengan meteri serta menggunakan media sebagai alat bantu. 3) menutup pembelajaran; kegiatan penutup dalam pembelajaran adalah kegiatan yang dilakukan untuk mengakhiri kegiatan pembelajaran. Pada proses ini guru melakukan evaluasi maupun pengayaan terhadap materi yang disampaikan, dapat pula memberikan reward terhadap siswa yang telah mencapai hasil belajar yang baik.

Dalam pelaksanaan kegiatan pembelajaran di SD Alam Cikeas menerapkan pendekatan saintifik atau pendekatan berbasis proses keilmuan yang menggunakan pembelajaran kontekstual. 
Dalam pengembanganya, model pembelajaran experiential ini diintegrasikan dengan kurikulum SD Alam Cikeas. Muatan kurikulum pada sekolah alam seperti greenlab outbond, cooking day merupakan gambaran pelaksanaan pembelajaran sekolah alam yang menggunakan model experiential.

Model experiential learning menekankan peserta didik pada sebuah kegiatan eksperimen. Model experiential bisa diterapkan ke dalam banyak pelajaran dengan kegiatan yang bervariasi. Model pembelajaran experiential bertujuan untuk mengembangkan pemahaman dan capaian hasil belajar lainnya melalui tranformasi pengalaman. Pengalaman sebagai proses dan sumber belajar merupakan fokus utama model pembelajaran ini.Model pembelajaran ini dikembangkan oleh David Kolb ini didasarkan pada teori pembelajaran Eksperimen (Experiential Learning Theory) sebagahal ini dijelaskan dalam bukunya Experiential Learning: Experiential as the Sourse of Learning and Development (1984). Model ini menekankan dua pendekatan yang saling berkaitan dalam memahami sebuah pengalaman yakni pengalaman konkret dan konseptualisasi abstrak, serta dua pendekatan dalam mengubah pengalaman yakni observasi refleksi dan eksperimen aktif. (Huda, 2013)

Model pembelajaran experiential bertujuan mengintegrasikan teori dan praktik pembelajaran agar peserat didik memperoleh pemahaman terhadap suatu teori pembelajaran secara utuh. Kolb mengembangkan model pembelajaran experiential secara sederhana dimulai dengan melakukan (do), mengamati (observ), merefleksikan (reflect) dan kemudian menerapkan (apply). Demikian seterusnya kembali ke langkah pertama. Terdapat 4 tahapan dalam Model
Experientia learningl, diantaranya : 1) pengalaman konkret 2) observasi refleksi 3) konseptualisasi abstrak 4) percobaan aktif. Kelebihan model pembelajaran experiential ialah hasilnya dapat dirasskan bahwa pembelajaran lewat pengalaman lebih efektif dan dapat memcapai tujuan secara maksimal. Kelemahannya, tidak semua materi pembelajaran yang dapat dianalisis dan direkonstruksikan dengan model ini, karena tidak semua pengalaman dapat dikaitkan dengan teori yang relevan. Dalam hal ini guru harus pandai dan kreatif dalam menemukan metode pembelajara yang tepat dan sesuai agar pembelajara dengan model experiential dapat tercapai dengan optimal

Mengacu pada tahapan kegiatan pembelajaran model experiential yang dikembangkan David Kolb yakni : Proses mengalam (experience), brbagi (share), analisi pengalaman (proccess), mengambil kesimpulan (generalize), dan menerapkan (apply). Pada pelaksanaannya SD Alam Cikeas, menerapkan experiential learning sesuai dengan tahapan yang dikemukakan David Kolb tersebut.

Kegiatan pembelajaran experiential yang di terapkan di SD Alam Cikeas diantaranya Greenlab, atau biasa dikenal dengan berkebun merupakan kegiatan mengenal, mennam dan merawat tanaman. Kegiatan ini diterapkan mulai dari peserta didik level 1 hingga level 6. Greenlab diawali dengan mengenalkan bibit atau tunas tanaman yang akan ditanam. Proses pertumbuhan dan pemakaian pupuk juga dijelaskan sebelum melaksanakan kegiatan menanam. Kegiatan ini didukung dengan sarana prasarana yang memadai di SD Alam Cikeas, seperti lahan berkebun, alat-alat pertanian, pupuk. SD Alam Cikeas juga memiliki ternak kambing dan kelinci, sehingga siswa bisa belajar membuat pupuk dari kotoran ternak tersebut. Setiap peserta didik memiliki 
atribut berkebun sendiri, seperti baju khusus kegiatan greenlab, topi yang terbuat dari daur ulang sampah plastik, sarung tangan dan sepatu boots.

Seperti yang telah disampaikan bahwa setiap kegiatan pembelajaran experiential, dikaitkan dan saling dihubungan keberbagai mata pelajaran. Tentunya kegiatan ini sangat erat kaitannya dengan pelajaran lainnya seperti matematika, sosial, sains dan agama. Peserta didik bisa belajar matematika melalui greenlab dengan mengukur tinggi tanaman, mengukur berat buah yang dipanen dan menghitung harga tanaman yang mereka tanam, mengukur diameter pohon, menghitung lubang biopori, menghitung volume pupuk komunal. Kaitannya dengan sosial, kegiatan greenlab ini mengajarkan kerjasama dan saling percaya antar teman. Kaitannya dengan sains tentunya siswa belajar tidak hanya sekedar mengetahui melainkan menglami apa yang ia pelajari seperti menanam, memberi pupuk, dan merawat tanaman tersebut. Dari sisi pendidikan Agama, peserta didik diajarkan bagaimana bersyukur atas indah dan luar biasanya makhluk cipataan Allah.

Diawal tahun, masing-masing kelas merencanaka program agribisnisnya. Program agribiisnis ini berkaitan dengan pelajaran greenlab. Produk greenlab yang dimiliki setiap kelas dipamerkan pada Pasar Kemis. Pasar Kemis merupakan akronim dari kegiatan Program Agrobisnis. Pasar Kemis ini merupakan tempat bagi siswa untuk belajar berwirausaha dari hasil proyek greenlab. Kegiatan lainnya yakni mengelola sampah, sesuai dengan prinsip Sekolah Alam Cikeas belajar menggunakan alam dan mengkaji masalah alam yang terintegrasi dengan lingkungan, untuk itu kegiatan mengelola lingkungan merupakan wujud kecintaan terhadap. Kegiatan ini diantaranya berkampanye kepada masyarakat. Kegiatan ini didukung dengan ketersediaan sarana 3R (Reuse, Reduse, Ricycle).

\section{Evaluasi Model Experiential Learning}

Evaluasi merupakan suatu tolak ukur dalam keberhasilan belajar siswa. Kegiatan akhir pembelajaran yakni, evaluasi pembelajaran adalah sebuah proses pengumpula data untuk menentukan sampai mana, dalam hal apa, dan bagaimana tujua pembelajaran sudah tercapai. (Arikunto, 2013). Dalam pembelajaran, pendidik adalh pihak yang paling bertanggungjawab dalam evaluasi. Dengan demikian pendidik patut dibekali dngan ilmu yang mendkung tugasnya, yakni mengevaluasi hasil belajar pesera didik. Tujuan evaluasi pembelajara pada hakikatnya adalah mengharapkan perubahan perilaku yang positif pada peserta didik. Oleh karena itu dalam evaluasi harus diperiksa sampai mana perubahan perillaku peserta didik. Evaluasi pembelajaran terdapat 2 jenis yakni: Tes dan Non-Tes. Tes meruapakan teknik penilain yang biasanya diolah secara kuantitatif, kemudian ditafsirkan tingkat penguasan kompetensi peserta didik. Non tes biasanya digunaka untuk menilai asppek tingkah laku termasuk sikap, minat, dan motivasi. Beberapa jenis non tes sebagai alat evaluasi diantaranya wawancara, observasi, studi kasus, dan skala penialaian.

Evaluasi dari pembelajaran model experiential di SD Alam Cikeas dilakukan setelah selesai kegiatan. Evaluasi berupa lembar kerja (worksheet). Worksheet ini dapat berupa latihan soal, lembar pengamatan, dan projek kelas. Evaluasi lainnya ialah dengan menilai aktifitas gerak peserta didik melaui observasi. Yang terakhir ialah evaluasi self assesment dimana siswa tersebut menilai dirinya 
sendiri kemudian menyampaiakan apa yang telah ia capai.

Setiap kelompok harus mempresentasikannya lembar kerja hasil pengamatannya. Lembar kerja juga digunakan ketika siswa diberi tugas untuk mengumpulkan informasi melalui interview kepada guru atau teman maupun menggali informasi dari internet, majalah, atau koran dengan topik tertentu dan selanjutnya memaparkan didepan kelas.

Dalam rubrik penilaian terdapat simbol yang menggambarkan apa yang dimunculkan peserta didik dalam belajar. Terdapat sembilan karakter yang digambarkan dengan simbol, yakni : Intelegensi, Interpersonal, logical thingking, verbal, natural, logic, self observasi, body leanguage. Terdapat tiga kategori tingkatan hasil belajar siswa yang menunjukan interval nilai tertentu. Tiga kategori tersebut dijabarkan dalam tabel 1 :

Tabel 1 Kategori peserta didik berdasarkan capaian hasil belajara

\begin{tabular}{lll}
\hline Improving & Good & Excelent \\
\hline $70-74$ & $75-84$ & $85-100$ \\
\hline
\end{tabular}

Yang menarik dari sisi evaluasi di SD Alam Cikeas ini adalah sekolah ini memiliki tiga jenis rapot yang dibagikan setiap dua bulan sekali. Rapot ini dibagikan setiap satu tema bahasan selesai diajarkan, maka dalam satu semester SD Alam Cikeas membagikan raport sebanyak tiga kali. Tiga jenis raport tersebut diantaranya raport narasi, portofolio, dan raport diknas. Raport narasi yaitu laporan perkembangan peserta didik, disampaikan kepada orangtua pada dua bulan pertama. Raport portopolio yaitu pengembalian laporan lembar pekerjaan peserta didik (worksheet) kepada orangtu/ wali, diberikan dua bulan setelah raport narasi. Raport Diknas, seperti halnya sekolah pada umunnya SD Alam Cikeas memberikan raport kepada orangtua/wali setiap akhir semester. Raport ini berupaa rapor akadmik dan rapor akhlak. Hal ini dilakuka untuk membangun kerjasama yang baik antara guru dengan orangtua terhadap perkembangan siswa baik akademik maupun mental.

Pembelajaran dengan menerapkan model experiential learning ini diharapkan dapat menciptakan pembelajaran yang menyenangkan yang dapat memudahkan peserta didik dalam memahami sebuah konsep ilmu. Pembelajaran menyenangkan (joyfull instcruction) meruapakan suatu proses pembelajran yang didalamnya terdapat suatu hubungan yang kuat antara pendidik dan siswa, tanpa ada rasa terpaaksa atau tertekan (Mulyasa, 2017). Dalam hal penbelajaran yang menyenangkan, peserta didik lebih diarahka untuk mempunyai motivasi tinggi dlam belajar dengan menciptakn situasi yang menyenangkan. Supaya motivasi belajar tetap tinggi, guru perlu memberikan umpan balik dari hasil belajar yang telah dicapai atau tugas yang telah diselesaikan oleh siswaa. Feedback tersebut dapat berupa reward, atau memberikan pujian. Hal ini penting dilakukan mengingat pentingnya peran pemberian apresiasi yang diberikan guru dalam meningkatkan motivasi belajar siswa.

Proses pembelajaraan yang menyenangkan bisa dilaksanakan dengan pertama mengatur ruangan yang rapi, indah, dan menarik, yaitu yaang memenuhii unsur kesehatann, segar dan bersih, bebas dari debu, lukisan dan karya-karya tertata rapi. Lingkungan belajar yang indah selain menarik, juga dapat memberi nilai keindahan sehingga membangktitkan motivasi belajar siswa. Kedua, dengan pengelolaan pembelajaraan yang hiidup dan 
bervariasi, yakni dengan menggunakan polla dan model pembelajara, media dan referensi belajar yang berhubungan serta gaya tubuh guru yang dapat membangkitkan kemauan belajar siswa (Prastowo, 2017).

Terkait hal tersebut Rose dan Nicholas, menyebutkan beberapa cara membuat aktifitas pembelajaran yang menyenangkan, diantaranya: menciptakan lingkungan belajar tanpa tekanan, menjamin subjek belajar berhubungan, menjamin bahwaa secara emosional positif, melibatka semua indra, menantang otak siswa untuk berfikir jauh kedepan. Hal mendasar yaang harus dilakukaan guru dallam rangka membuat pembelajaran yang menyenangkaan, antara lain: menyapa siswa dengan ramah dan seemangat, menciiptakan suasanaa rileks, memotivasii peserta didik, memakai ice breaking, dan menggunakan metode yang variatif.

\section{Pembahasan}

Berdasarkan permasalaahan yang diangkat yakni mengenai pengelolaan pembelajaran khususnya pada pembelajaran model experiential, diperoleh data selama wawancara dan pengamatan lapangan mengenai perencanaaan, pelaksanaaan, dan evaluasi model experiential learning. Experiental model merupakan model pembelajaran yang mengaktifkan siswa untuk memperoleh informasi atau ilmu pengetahuan melalui sebuah pengalaman. Perencanaan pembelajaran yang tersusun secara teratur, telah menjabarkan secara jelas dan rinci kegiatan pembelajaran. Kegiataan pebelajaran dilakukan sebanyak $75 \%$ outdoor dan $25 \%$ indoor. Untuk itu, model experiential dilakukan dengan mengintegrasikan kurikulum sekolah alam terpadu yang dapat dimaknai kedalam berbagai bidang ilmu. Pada tahap evaluasi kegiatan pembelajaran experiential dilakukan setiap akhir kegiatan, alat evaluasi dapat berupa lembar pengamatan, hasil karya, menilai aktivitas siswa selama kegiatan, maupun kemampuannya dalam menyimpulkan hasil kegiatan. Berdasarkan teori pengelolaaan pembelajara yang berupa perencanaan, pelaksanaan, dan evaaluasi pembelajaran serta teori model experiential learning, dan pengamatan selama dilapangan kegiatan pembelajaran di SD Alam Cikeas.

\section{KESIMPULAN DAN IMPLIKASI}

\section{Kesimpulan}

Berdasarkan hasil penelitian yaang telah dilakukan di SD Alam Cikeas dapaat diambil simpulan bahwa:

1. Perencanaan pembelajaran model pembelajaran experiential di SD Alam Cikeas dibuat dengan mengacu pada kurikulum Pendidikan Nasional dan kurikulum sekolah alam. Perencanaan pembelajaran diupgrade setiap tahunnya. Dalam hal ini kepala sekolah dan litbang bertindak sebagai penyusun kurikulum terpadu SD Alam Cikeas yang mana mengintegrasikan kurikulum diknas dengan kurikulum sekolah alam. Selanjutnya pendidik bertanggung jawab terhadap penyusunan rencana pembelajaran. Seperangkat perencanaan pembelajaran terdiri dari: Kalender Akademik, KKM (Kriteria Ketutasan Minimal), Tema, Spider Web, Time Table, Weekly Plan, Daily Plan.

2. Pelaksanaan pembelajarran di SD Alam Cikeas lebih sering digunakan model experiential. Hal ini dianggap sesuai dengan konsep alam, yakni belajaran melalui pengalaman. Kegiatan pembelajaran banyak dilakukan diluar 
ruangan, yakni dengan memanfaatkan lingkungan dan potensi lokal SD Alam Cikeas sebagai sumber belajar. Setiap kegiataan pembelajaran dengan model experiental baik melalui eksplorasi alam maupun melalui kegiatan sosial diintegrasikan pada setiap mata pelajaran baik matematika, sains, sosial, bahasa, agama dan lain lain. Model experiential learning dilakukan melalui 4 tahapan mengalami, mengobservasi, merefleksi, dan memberikan pengalaman secara terstruktur. Sarana prasarana yang tersedia seperti sekolah lainnya, SD Alam Cikeas juga didukung dengan fasilitas lainnya yang menjadi ciri khas sekolah alam. Fasilitas tersebut diantaranya : sarana outbond, lahan perkebunan, lahan peternakan, sarana berwirausaha, fasilitas 3R(Reduce, Reuse, Recycle), observatorium, dan berbagai jenis tanaman dan pepohonan yang tumbuh dilingkungan SD Alam Cikeas menjadi media belajar bagi peserta didik.

3. Kegiatan belajar melalui model experiential learning guru memberikan worksheet yang merupakan lembar kerja yang harsu diisi sebagai hasil dari pengamatan. Worksheet ini menjadi bahan evaluasi bagi guru dalam menilai hasil belajar siswa. Worksheet dapat berupa lembar pegamatan, latihan soal, dan projek kelas. Selain melalui worksheet, evaluasi juga dilakukan melalui penilaian aktifitas gerak peserta didik melaui observasi yang dilakukan guru. Yang terakhir ialah melalui self assesment dimana peserta didik tersebut menilai dirinya sendiri kemudian disampaikan. Dari evaluasi tersebut guru dapat menarik kesimpulan dari ketercapaian hasil belajar peserta didik. Hasil evaluasi pembelajaran menjadi tolak ukur keberhasilan peserta didik dalam kegiatan belajar.

\section{Implikasi}

Banyak hal yang penulis dapatkan selama proses penelitian di SD Alam Cikeas mengenai pengelolaan experiential learning pada sekolah alam untuk menciptakan pembelajaran yang menyenangkan. Dalam hal ini peneliti memberikan saran sebagai masukan dan harapan agar sekolah yang menjadi tempat penelitian dapat terus berkembang. Saran disampaikan kepada pihak terkait, yakni pihak lembaga pendidikan yang menjadi tempat penelitian. Adapun saran tersebut adalah sebagai berikut :

1. Dimasa yang akan datang peneliti berharap agar Sekolah Alam Cikeas dapat terus mengembangkan rencana pembelajaran khususnya pada model pembelajaran experiential, yang mengikuti perkembangan zaman dan dinamika yang terjadi di masyarakat.

2. Peneliti berharap kedepannya sebaiknya guru juga memperhatikan dan mempertimbangkan lamanya waktu yang dibutuhkan dalam pelaksanaan model experiential learning, sehingga pada pelaksanaannya dapat selesai dengan tuntas sampai kepada tahap anak dapat menarik kesimpulan dari kegiatan. Selain itu agar peserta didik dapat menerima informasi secara utuh, sebaiknya guru memberikan review pada setiap akhir kegiatan. Hal ini sekaligus juga memberikan koreksi kepada peserta didik apabila terdapat hal yang perlu diluruskan.

3. Dimasa yang akan datang peneliti berharap evaluasi pembelajaran di SD Alam Cikeas dapat terus berkembang dengan menemukan metode baru dalam mengukur keberhasilan belajar peserta 
52 Pujaningtyas et al.

didiknya. Peneliti juga berharap agar guru dapat menemukan alternatif atau solusi yang tepat apabila terdapat peserta didik yang belum mencapai standar dalam ketercapaian keberhasilan belajar.

\section{DAFTAR PUSTAKA}

Arikunto, S. (2013). Dasar-Dasar Evaluasi Pendidikan Edisi 2. Jakarta: Bumi Aksara.

Huda, M. (2013). Model-Model Pengajaran dan Pembelajaran. Yogyakarta: Pustaka Belajar.

Mulyasa. (2017). Menjadi Guru Profesional,Menciptakan Pembelajaran
Model experiental learning pada sekolah alam

Kreatif dan Menyenangkan Cet 15. Bandung: Remaja Rosdakarya.

Prastowo, A. (2017). Menyusun Rencana Pelaksanaan Pembelajaran (RPP) Tematik Terpadu. Jakarta: Fajar Interpratama Mandiri.

Silberman, M. (2007). The Handbook of Experiental Learning. San Fransisco: Pfeiffer.

Thobbroni, M. (2015). Belajar dan Pembelajaran Teori dan Praktik. Yogyakarta: Ar-Ruzz Media.

Yusuf, A. M. (2014). Metode Penelitian Kualitatif, Kuantitatif dan Penelitian Gabungan. Jakarta: Fajar Interpratama Mandiri. 